\title{
Is the role of academics as teachers changing? An exploratory analysis in Italian universities
}

\author{
Giovanni Barbato, Roberto Moscati, and Matteo Turri*
}

doi: http://dx.doi.org/10.18543/tjhe-6(2)-2019pp97-126

Received: 14-01-2019

Accepted: 27-03-2019

\begin{abstract}
University teaching is under pressure to evolve in line with the social, cultural and economic changes of modern society. This process inevitably affects the professional profile of academics since it creates an increasing tension between the traditional modes of teaching and the learning styles and professional expectations of students. This article analyses, both theoretically and empirically, the process of change of university teachers in the face of today's challenges. The empirical analysis is based on the Italian university system, which has always been characterised by an overall reluctance to reforms. This article presents a theoretical framework based on two dimensions, i.e., the teacher/university relationship and the teacher/ student relationship, to investigate the evolution of the professional profile of academics as teachers on the basis of seven teaching practices identified in the literature. The findings show that, besides some limits that are specific to professional bureaucracies, the support of universities is fundamental to promote innovation in teachers' teaching practices, which are otherwise regulated and shaped only by their disciplinary community.
\end{abstract}

Keywords: Academics; Italian higher education system; professional profile; teaching activity; teaching innovation.

* Giovanni Barbato (giovanni.barbato@unimi.it), PhD in Economic Sociology and Labour Studies, is presently Post-doctoral student at the Department of Economics, Management and Quantitative Methods (DEMM), Università degli Studi di Milano (Italy).

Roberto Moscati (roberto.moscati@unimib.it), is full professor of Sociology of Education at the University of Milano-Bicocca (Italy).

Matteo Turri (matteo.turri@unimi.it), PhD in Management, is presently Associate Professor in Public Management in the Department of Economics, Management and Quantitative Methods (DEMM), Università degli Studi di Milano (Italy).

More information about the authors is available at the end of this article. 


\section{The changing nature of the teaching activity}

After decades of research supremacy, the teaching dimension of university is now at the centre of a renewed attention by both scholars and policy makers as an equally important academic activity. ${ }^{1,2}$ This transformation inevitably affects the academics' identity. In turn, the academics' understanding of their role as teachers impacts on the organisation and the activities and contents of teaching itself. Thus, it is a key aspect in the processes of innovation and development of university teaching., ${ }^{3,4,5,6}$

In particular, there is a need to rethink both the contents and methods of university courses. This need has arisen more or less rapidly in relation to individual disciplines and is a novelty in the international academic community. Indeed, for many years, a strong emphasis was placed on scientific research as the main focus of the significance of universities.

There are various reasons for this change. First of all, there is a stronger and stronger need to educate students for a new complex future and prepare them for the uncertain, the unknown, the unforeseen, rather than for what is already known based on the knowledge gathered over the years (as in the

${ }^{1}$ Marcia Devlin and Gayani Samarawickrema, "The criteria of effective teaching in a changing higher education context," Higher Education Research and Development 29 (2010): 111-24, https://doi.org/10.1080/07294360903244398.

2 Alenoush Saroyan and Keith Trigwell, "Higher education teachers' professional learning. Process and outcome," Studies in Educational Evaluation 46 (2015): 92-101, https:// doi.org/10.1016/j.stueduc.2015.03.008.

3 Alenoush Saroyan and Cheryl Amundsen, "Evaluating university teaching. Time to take stock," Assessment \& Evaluation in Higher Education 26 (2001): 341-53, https://doi. org/10.1080/02602930120063493.

${ }^{4}$ Ester A. Hoehle and Ulrich Teichler, "The teaching function of the academic profession," in The work situation of the academic profession in Europe: Findings of a survey in twelve countries, ed. Ulrich Teichler and Ester A. Hoehle (Dordrecht: Springer, 2013), 79-108.

${ }^{5}$ Lanqin Zheng, Xin Li, and Fengying Chen, "Effects of a mobile self-regulated learning approach on students' learning achievements and self-regulated learning skills," Innovations in Education and Teaching International 55 (2018): 616-24, https://doi.org/10.1080/14703297.2 016.1259080 .

${ }^{6}$ Cristina Coggi and Paola Ricchiardi, "Developing effective teaching in higher education,” Form@re - Open Journal Per La Formazione In Rete 18 (2018): 23-38, https://doi. org/10.13128/formare-22452. 
pedagogic-didactical tradition so far) ${ }^{7,8,9}$ On the other hand, this renewed interest in civic culture (which is traditionally more widespread in Englishspeaking and Scandinavian countries) is associated with the need to adapt knowledge to the changes in production processes and professional figures following the evolution of the economic structures. The skills required to succeed are mainly the so-called 'soft skills' which complement disciplinary knowledge. ${ }^{10,11}$ These specifically involve team-work skills, communication skills, leadership skills, decision-making skills and problem-solving skills. The need to review the educational provision of universities also results from the requirements established by quality assurance agencies and assessment mechanisms whereon an increasing share of direct (public) and indirect (private, prestige-based) funding is based. ${ }^{12}$ This results in the need to maintain a positive ratio between enrolled students and graduates, thus decreasing the number of drop-outs.

This combination of reasons also stems from the growing attention to the problem of matching the educational offer to students' different characteristics. This issue - although not new, as it arose with the exponential spread of the aggregate demand of HE in the 1960s - has become relevant again in relation to the characteristics rather than the diversification of the offer (different parallel sources or more levels in sequence), as previously. Hence, the experimentation of different curricula, the inclusion of metadisciplines, the combination of on-site and distance learning (MOOCs, blended courses), and, more generally, the spread of the idea that students

7 Larry D. Shinn, "Liberal education in the age of the unthinkable," Change: The Magazine of Higher Learning 44 (2012): 15-21, https://doi.org/10.1080/00091383.2012.6918 58 .

${ }^{8}$ Ulrich Teichler, "Changing perspectives. The professional relevance of higher education on the way towards the highly-educated society," European Journal of Education 50 (2015): 461-77, https://doi.org/10.1111/ejed.12146.

${ }^{9}$ Helga Nowotony, The cunning of uncertainty (Cambridge: Polity Press, 2016).

${ }^{10}$ David Billing, "Teaching for transfer of core/key skills in higher education: Cognitive skills," Higher Education 53 (2007): 483-516, https://doi.org/10.1007/s10734-005-5628-5.

${ }^{11}$ Fátima Suleman, "The employability skills of higher education graduates: Insights into conceptual frameworks and methodological options," Higher Education 76 (2018): 263-78, https://doi.org/10.1007/s10734-017-0207-0.

${ }^{12}$ David D. Dill and Maarja Soo, "Academic quality, league tables, and public policy: A cross-national analysis of university ranking systems," Higher Education 49 (2005): 495-533. https://doi.org/10.1007/s10734-004-1746-8. 
must be directly involved in learning processes (interactive education, cooperative learning). ${ }^{13,14}$

The support of teachers plays a central role in the process of improving teaching. In many cases, a change in the traditional teaching methods is required. This change is not always simple, as the relationship between teachers and students corresponds to a specific perception of roles whose modification requires an adaptation effort on the part of both. If students are used to a passive reception of knowledge they will find it hard to acquire a cooperative attitude, fostering a critical reflection on the transmission of information in the classroom. On the other hand, teachers will have to use dialogue-based and team-oriented methods which are very different from the traditional conference-based lesson that characterises the frontal lecturing method. ${ }^{15,16}$

After analysing the professional role of university teachers, this article focuses on the teacher/institution and the teacher/student relationship as key factors in the exploration of the evolution of the role of university teachers through the analysis of seven teaching practices and procedures identified within the HE literature.

These factors were investigated in the Italian university system which is characterised by a Humboldtian nature, a Napoleonic administrative tradition and a strong guild-based structure ${ }^{17,18}$ which can highlight the factors that both hamper and support the evolution of the academics as teachers.

13 Alexander W. Astin, "Student involvement: A developmental theory for higher education," Journal of College Student Personnel 25 (1984): 297-308.

${ }^{14}$ Bo K. Choi and Byung S. Rhee, "The influences of student engagement, institutional mission, and cooperative learning climate on the generic competency development of Korean undergraduate students," Higher Education 67 (2014): 1-18, https://doi.org/10.1007/s10734013-9637-5. 2009).

${ }^{15}$ Noel Entwistle, Teaching for understanding at university (Basingstoke: Palgrave,

${ }^{16}$ Elisabetta Nigris, "Learning to teach: the pilot programme to improve faculty members teaching skills at the University of Milano-Bicocca," Form@are - Open Journal Per la Formazione in Rete 18, no. 1 (2018): 53-66, https://doi.org/10.13128/formare-22603.

${ }_{17}$ Burton R. Clark, Academic power in Italy. Bureaucracy and oligarchy in a national university system (Chicago: The University of Chicago Press, 1977).

${ }^{18}$ Giliberto Capano, Marino Regini, and Matteo Turri, Changing governance in universities. Italian higher education in comparative perspective. (London: Palgrave Macmillan, 2016). 


\section{New roles of university and new professional roles of academics}

In this uncertain scenario, a potential weakness has been identified: the difficulty or even the inability of academics to fully define their professional profile in general terms of roles and responsibilities with respect to society and, more specifically, in the field of teaching functions. ${ }^{19,20,21,22}$

In fact, the general question about whether academics are professionals has been debated for years since professionalism is a term encompassing many elements. Everett C. Hughes made a distinction between scientist, who do not have clients and professionals who do. Consequently, academics as scientists do not clients and therefore are not professionals, but in their role as teachers they have students. Hence, the subsequent question is whether students can be considered as clients. One position maintains that they are not really clients since "university faculties are experts in their various disciplines and not in teaching, which finds institutionalized expression in the fact that they are neither trained nor licensed to teach". ${ }^{23,24}$

Nevertheless, for the majority of authors the academic staff is included into the so called "person professions" together with those in fields like medicine, law and religion. Here the relationship between professional and client is crucial and implies the trust of clients as well as of the community through the professional's competence, integrity and ethics. ${ }^{25}$ "For instance, norms covering client relations dictate that the professional be impersonal and objective (limit the relationship to the technical task and hand, avoid emotional involvement), and impartial (not discriminate, give equal service regardless of personal sentiment)". ${ }^{26}$

19 Peter M. Blau, The organization of academic work (New York: John Wiley \& Sons, 1973).

${ }^{20}$ Roberto Moscati, Chi governa l'università? Il mondo accademico italiano tra conservazione e mutamento, ed. Roberto Moscati (Napoli: Liguori, 1997).

${ }^{21}$ Séverine Louvel. "Understanding change in higher education as bricolage: how academics engage in curriculum change," Higher Education 66 (2013): 669-91, https://doi. org/10.1007/s10734-013-9628-6.

${ }^{22}$ Ulrich Teichler, Akira Arimoto, and William K. Cummings, The Changing Academic Profession. Major Findings of a Comparative Survey (Dordrecht: Springer, 2013).

${ }^{23}$ Peter M. Blau, The organization of academic work (New York: John Wiley \& Sons, 1973).

${ }^{24}$ Everett C. Hughes, Men and Their Work (New York: The Free Press, 1958).

${ }^{25}$ David W. Piper, "Are professors professionals?," in The organization of university examination, ed. David W. Piper (London: J. Kingsley, 1994), 1-18.

${ }^{26}$ Harold L. Wilensky, "The professionalization of everyone?," American Journal of Sociology 70 (1964): 137-158. 
An ideological conception of professions endows university teachers with three fundamental characteristics: (i) the principle of vocation (the 'calling') which stems from the craft sector and the inherent value of work, (ii) the idea of 'universal service', intended as a pre-industrial protection of the 'social factory' from the disruptive effects of the market, (iii) the aversion to commercial scopes based on the conviction that a high social class imposes duties and confers rights (the notion of 'noblesse oblige' of Larson-Sarfatti (1977) ${ }^{27}$ The combination of these characteristics contributes to strengthening the individual bases of the professional ethos and accounts for the focus on the autarchic dimensions of self-management and selfregulation of this professional category, following the idea of solidarity which is traditionally claimed and often shaped into Medieval guilds..$^{28,29}$ However, this tendency somehow contrasts with the involvement of other professional figures in the organisation of the services provided to citizens which developed with the emergence of welfare systems and when the State started to be a client of professions. Therefore, in contemporary society, there is no place for community organisations such as guilds. Hence, in each country, the professional regulation systems that once were considered antithetical (such as bureaucracy, market and self-regulation) became compatible in various ways. ${ }^{30}$

However, it was also observed that university teachers tended to interpret the relational dimensions of the profession as individual aspects that could be generalised. Their relationships are perceived as resulting from novel decisions and personal engagement and not as the product of common institutional conditions. The lack of perception of a common professional condition and of an organisational cohesion corresponds to the traditional model of university teacher whose aim is to replicate the élites and pursue basic research, but it does not correspond to a fundamental characteristic of people-related professions: the compliance with the rules of professionalism.

${ }^{27}$ Magali Larson-Sarfatti, The rise of professionalism: A sociological analysis (Berkeley: The University of California Press, 1977).

${ }^{28}$ Elliott A. Krause, "Les guildes, l'Etat et la progression du capitalisme. Les professions savantes des 1930 à nos jours," Sociologie et Sociétés 20, (1988): 91-124, https://doi. org/10.7202/001391ar.

${ }^{29}$ Burton R. Clark, Academic power in Italy. Bureaucracy and oligarchy in a national university system (Chicago: The University of Chicago Press, 1977).

${ }^{30}$ Jürgen Enders, Academic staff in Europe. Changing contexts and conditions (London: Greewood Press, 2001). 
In short, with respect to the most of the relations outlined, the academic fits rather well, but the professor typically does not see the mas organized structures, as common conditions, but as individual decisions and commitments. On only one major trait does this pattern fail, that of organizational cohesion, but this is compensated for to a considerable extend by the frequency of interaction among academics, and the informal exchange of information and judgements. ${ }^{31}$

In short, the emergence of mass $\mathrm{HE}$ and the new functions of universities contrast with this interpretation of the professional role, particularly in relation to the relationship between teacher and institution and teacher and students.

\section{The relationships between teacher and university and between teacher and students}

In order better to understand the evolution of this process, it is helpful to examine the characteristics that are typical of the academic profession. Like other professions, academia is characterised by a highly institutionalised individualism. Traditionally, its members were socialised within wellestablished institutional contexts (i.e., universities) that were intended as structures aimed at providing support to creativity and criticism. Academics were allowed to individually interpret their professional role in an informal regulatory framework built over time by one's peers.

The academic communities have encouraged their members to show their freedom, intellectual originality and quality, which are often acquired by building networks beyond national and disciplinary boundaries in individual paths. This results in the widespread pride of being able to ignore or control the power of academic institutions. ${ }^{32}$ Thus, in a fully internalised perspective, the 'republic of science' is a place where it is possible to pursue collectively the truth in a safe space with well-defined borders. ${ }^{33}$ Therefore, the university acts as an intermediary for individuals who are devoted to

31 William J. Goode, "The theoretical limits of professionalization." in The semiprofessions and their organization, ed. Amitai Etzioni (New York: The Free Press, 1969), 266-313.

${ }^{32}$ Christine Musselin, "Redefinition of the relationships between academics and their university," Higher Education 65 (2013): 25-37, https://doi.org/10.1007/s10734-012-9579-3.

${ }_{33}$ Michael Polanyi, "The republic of science. Its political and economic theory," Minerva 1 (1962): 54-73. 
altruism, truth and pure research..$^{34,35}$ The relationship between university teachers and university (dimension I) is thus the first level of analysis to examine the evolution of the professional role of university teachers. This environment, which is based on the right to self-regulation, on the freedom and the trust inherently conferred by society, and where the unifying element is a scholar's discipline rather than the university eventually did end up in crisis. In a few words, we can observe that the more advanced knowledge is pivotal in society, the higher the demand to acquire it and the more sought-after are the people who have this knowledge. There is thus a demand to control knowledge and steer its direction, whilst the domain of disciplines is called into question. Overall, this process marks a deep change in universities which are no longer intended specifically to educate élites but are increasingly influenced by economic and political forces. This results in a growing system of norms, rules and procedures that academics are required to comply with. This also highlights the process of increasing the autonomy of each university. This autonomy fosters new forms of coordination and institutional policies whose overall result - particularly when they are supported by evaluation procedures - is a decreasing organisational autonomy for teachers.

This tendency also impacts on knowledge transfer processes, as well as on professional skills transfer where students - intended as 'clients'assume a crucial role. In this respect, a few peculiarities in the academic environment should be pointed out. Generally, in a professional job, the relationship with a client has multiple implications. For instance, the fundamental competences of a profession are: (a) the acknowledgement of the client's conditions and needs and (b) the provision of appropriate management of these.$^{36}$ In the first case, the issue is whether students are to be considered as the 'clients' of teachers, who are neither trained nor certified as teachers. ${ }^{37}$ Yet one must take into account how the roles of teacher/scholar and client/student change in relation to the evolution of university functions. In the past, the relationship was between a scholar and students who were also supposed to become either members of the

${ }^{34}$ Burton R. Clark, The higher education system. Academic organization in crossnational perspective (Berkeley: University of California Press, 1983).

${ }^{35}$ Mary Henkel, Academic identities and policy change in higher education. (London: Jessica Kingsley Publisher, 2000).

${ }^{36}$ Henry Mintzberg, The structuring of organizations: A synthesis of research (Englewood Cliffs: Prentice-Hall, 1979).

${ }^{37}$ Peter M. Blau, The organization of academic work (New York: John Wiley \& Sons, 1973). 
ruling class or scholars and thus their teachers' peers. Now, the spread of the mass university seems to promote a relationship that is closer to a professional/client relationship (in a peculiar way, since here the client does not directly pay for the professional's services). Moreover, there has been a crucial change in the aims and expectations of new students/ clients. Nowadays, only a small minority of students will pursue an academic career and join the professional/teacher community; and similarly, very few students will be part of the ruling classes or the intellectual élites. Therefore, the role of teachers has shifted from training future members of the ruling class or academics to providing professional competences to clients. All these transformations have produced a progressive transfer of emphasis from the teaching to the learning model ${ }^{38}$. This leads to a number of (so far neglected) consequences in terms of professional codes of ethics, internal controls and relationships between professionals and institutions, all of which clash with academic traditions and the understanding of the academics' role and identity. ${ }^{39}$ Thus, in this framework, the new relevance of teaching methods touches on the sensitive issue of the proper functioning of universities in relation to the demands/expectations of society. This is why the relationship between teachers and students (dimension II) is the second level of analysis and it becomes crucial to investigate the new roles of university teachers.

\section{The Italian reality}

It is believed that the Italian reality can be particularly fruitful since it offers the opportunity to investigate the demand for change and innovation of the professional figure of academics in a context that is traditionally characterised by conservative attitudes and resistances to changes. As already mentioned, three characteristics of the Italian HE system contribute to this: (i) the Humboldtian nature; (ii) the Napoleonic administrative tradition and the (iii) 'guild-based structure'.

38 John Dirkx and Anna Serbati, "Promoting faculty professional development: strategies for individual and collective reflection towards institutional change," in Preparare alla professionalità docente e innovare la didattica universitaria, ed. Ettore Felisatti and Anna Serbati (Milano: Franco Angeli, 2017), 21-28.

${ }^{39}$ Roberto Moscati, Come e perché cambiano le università in Italia e in Europa, ed. Roberto Moscati (Napoli: Liguori, 2010). 
First of all, the Italian HE system has been historically influenced by a Humboldtian prospective, according to which the role of universities and academics stems from the simultaneous pursuing of basic research and education of future élites. ${ }^{40}$ However, as already described above, the combination of 'research dominion' and mass education makes this dualistic balance increasingly fragile, and even more so in an undifferentiated HE system such as the Italian one. ${ }^{41}$ On the one hand, the performance-based funding mechanism of universities and the career of the academics are clearly based only on their research performances. On the other, the teaching load and the student-teacher ratio within the Italian universities are becoming increasingly demanding as a result of mass education. These two opposite tensions inevitably generate negative incentives to the integration of the research and teaching activity, with unavoidable but detrimental effects of the former over the latter, as well documented in literature. ${ }^{42,43}$ It follows that, despite the Humboldtian view of the academic profession, when teaching is barely related to the research activity (which is the case of undergraduate teaching), this is seen as 'something done for the institution', with a lower prestige of the former compare to the latter. ${ }^{44}$

Secondly, the Italian HE sector, as a component of the public administration, is characterised by a Napoleonic administrative tradition ${ }^{45,46}$ which makes the formal adherence to the administrative process and uniformity the most important success criteria. This 'legalistic' orientation has often reduced the expectations of innovative reforms concerning the HE

${ }^{40}$ Wiebke Esdar, Julia Gorges, and Elke Wild, "The role of basic need satisfaction for junior academics' goal conflicts and teaching motivation," Higher Education 72 (2016): 17590, https://doi.org/10.1007/s10734-015-9944-0.

${ }^{41}$ Aynur Y. Kaynardağ, "Pedagogy in HE: does it matter?," Studies in Higher Education 44 (2019): 1-9, https://doi.org/10.1080/03075079.2017.1340444.

${ }^{42}$ Peter M. Blau, The organization of academic work (New York: John Wiley \& Sons, 1973).

${ }^{43}$ Hugo Horta, Vincent Dautel, and Francisco M. Veloso, "An output perspective on the teaching-research nexus. An analysis focusing on the United States higher education system," Studies in Higher Education 37 (2012): 171-87, https://doi.org/10.1080/03075079.2010.50326 8 .

${ }^{44}$ Donald Light Jr., "The structure of the academic professions," Sociology of Education 47 (1974): 2-28, https://doi.org/10.2307/2112165.

${ }^{45}$ Burton R. Clark, Academic power in Italy. Bureaucracy and oligarchy in a national university system (Chicago: The University of Chicago Press, 1977).

${ }^{46}$ Stefano Boffo and Roberto Moscati, "Evaluation in Italian higher education system. Many tribes, many territories, many...godfathers," European Journal of Education 33 (1998): 349-360. 
sector, ${ }^{47}$ in particular New Public Management inspired reforms. These are indeed aimed at reducing the traditional freedom of academics in the teaching activity which becomes under the supervision of the administrative part of universities. In this view, the introduction of quality assurance practices has often been seen as mere additional bureaucratic procedures to be complied with in order to maintain its own autonomy.

Thirdly, Italian universities have been described by B. Clark ${ }^{48}$ as "guilds-based organizations", in other words, realities in which the autonomy of the individual is strictly linked to the strong role of the various disciplinary communities whose power shapes their ordinary operation. ${ }^{49}$ Key decisions are "in fact subject to pressure from the most powerful academic groups" 50 and academic activities are coordinated following a bottom-up logic based on collegial agreement generated within these scientific communities. Hence, the disciplinary communities exert a relevant role in relation to individual academics' reactions and attitudes towards external pressures and incentives. ${ }^{51}$ Consequently, different epistemological and deontological characteristics generate different interpretations of the role of academics as teachers $^{52}$ and, as a result, different degrees of resistance (or adjustment) to the demand for innovation and change are produced.

In conclusion, these three features created a fertile ground in which resistances to change and conservative attitudes towards innovation are combined, as shown in some empirical works ${ }^{53,54}$ Moreover, the traditional

${ }^{47}$ Giliberto Capano, Marino Regini, and Matteo Turri, Changing governance in universities. Italian higher education in comparative perspective (London: Palgrave Macmillan, 2016).

${ }^{48}$ Burton R. Clark, Academic power in Italy. Bureaucracy and oligarchy in a national university system (Chicago: The University of Chicago Press, 1977).

49 Stefano Boffo and Roberto Moscati, "Evaluation in Italian higher education system. Many tribes, many territories, many...godfathers," European Journal of Education 33 (1998): 349-360.

${ }^{50}$ Giliberto Capano, "Government continues to do its job: A comparative study of governance shifts in the higher education sector," Public Administration 89 (2011): 1622-1642, https://doi.org/10.1111/j.1467-9299.2011.01936.x.

${ }_{51}$ Tony Becher and Paul R. Trowler, Academic tribes and territories, $2 \mathrm{nd}$ ed. (Buckingham: Open University Press, 2001).

${ }_{52}$ Michele Rostan, La professione accademica in Italia. Aspetti, problemi e confronti nel contesto Europeo (Milano: LED, 2011).

${ }^{53}$ Stefano Boffo and Roberto Moscati, "Evaluation in Italian higher education system. Many tribes, many territories, many...godfathers," European Journal of Education 33 (1998): 349-360.

${ }^{54}$ Giliberto Capano, Marino Regini, and Matteo Turri, Changing governance in universities. Italian higher education in comparative perspective. (London: Palgrave 
resilience of Italian teachers is now being challenged by at least two related factors..$^{55}$

The first factor is of national importance: since 2013 an accreditation and quality assurance process was launched on the basis of the European Standards and Guidelines (ESG) published by ENQA (2005 and 2015), ${ }^{56}$ which focused on the way teaching is carried out at universities. The experience of other pioneering countries in the adoption of quality assurance systems suggests that the concrete effects of these practices be carefully verified ${ }^{57,58,59,60}$ Only in the future will it be possible to see whether the introduction of quality assurance will result in an improvement in teaching and learning or whether it will merely be a burden. ${ }^{61,62}$

The second factor, on the other hand, has a local dimension and concerns the launch of initiatives to improve teaching in some universities ${ }^{63}$ The common element of all of these is their voluntary character (with no

Macmillan, 2016).

55 Ettore Felisatti and Anna Serbati, Preparare alla professionalità docente e innovare la didattica universitaria (Milano: Franco Angeli, 2018).

${ }^{56}$ European Association for Quality Assurance in Higher Education (ENQA), "European Standards and Guidelines (ESG)"(2015), https://enqa.eu/index.php/home/esg/ [In English.].

${ }^{57}$ Lee Harvey and Jethro Newton, "Transforming quality evaluation," Quality in Higher Education 10 (2004): 149-65, https://doi.org/10.1080/1353832042000230635.

${ }^{58}$ Lee Harvey and Jethro Newton, "Transforming quality evaluation: Moving on," in Quality assurance in higher education, ed. Don F. Westerheijden, Bjørn Stensaker, and Maria J Rosa (Dordrecht: Springer, 2007), 225-245.

59 Theodor Leiber, Bjørn Stensaker, and Lee Harvey, "Impact evaluation of quality assurance in higher education: Methodology and causal designs," Quality in Higher Education 21 (2015): 288-311, https://doi.org/ 10.1080/13538322.2015.1111007.

${ }^{60}$ Sónia Cardoso, Maria J. Rosa, and Bjørn Stensaker, "Why is quality in higher education not achieved? The view of academics," Assessment \& Evaluation in Higher Education 41 (2016): 950-65, https://doi.org/10.1080/02602938.2015.1052775.

${ }^{61}$ Matteo Turri, "The new Italian agency for the evaluation of the university system (ANVUR): a need for governance or legitimacy?," Quality in Higher education 20 (2014): 6482, https://doi.org/10.1080/13538322.2014.889429.

${ }_{62}$ Tommaso Agasisti, Giovanni Barbato, Martina Dal Molin, and Matteo Turri, "Internal quality assurance in universities: does NPM matter?" Studies in Higher Education (November 2017), https://doi.org/10.1080/03075079.2017.1405252.

${ }^{63}$ Few relevant experiences have been developed when this research was carried out. Among them are worth to be mentioned: the PRODIT programme at the University of Padua concerning teacher training and teaching innovation, Bocconi Education and Teaching Alliance (BETA) mostly devoted to the use of new teaching methods and technological tools, and the teacher training initiative (QUID - Didactical Quality Innovation) promoted by the Sapienza University of Rome. For a more updated review of initiatives devoted to the didactical improvement in the Italian universities see http://www.fupress.net/index.php/formare/issue/ view/1489. 
obligation for teachers to participate) and their experimental character (specific projects that have not been made permanent so far). For the reasons highlighted so far, the Italian case study could be considered as a particularly fruitful reality to investigate the factors that both hamper and facilitate the evolution of the role of academics as teachers in mature HEIs.

\section{Research design and method}

As described in the third section, to investigate the role of university teachers one must examine the relationship between teacher and institution and that between teacher and student in the teaching activity. In the literature, very few studies on this topic take into account both relationships and even fewer in relation to Italian universities. A few exceptions are the studies carried out by R. Moscati ${ }^{64}$ S. Boffo et al..${ }^{65}$ and M. Rostan. ${ }^{66}$ This study, which is based on an exploratory approach, intends to fill this gap by analysing the evolution of the professional profile of university teachers. In particular, the research sets out to study the behaviour of university teachers in the main practices and activities of the teaching process, by investigating both the relationship between teachers and university (dimension I) and the relationship between students and teachers (dimension II). With an exploratory approach, this is the research question of this study.

Since there is not a shared classification of the practices involved in the teaching, some relevant empirical works have been analysed. ${ }^{67,68,69,70}$ Biggs

${ }^{64}$ Roberto Moscati, Chi governa l'università? Il mondo accademico italiano tra conservazione e mutamento, ed. Roberto Moscati (Napoli: Liguori, 1997).

${ }^{65}$ Stefano Boffo, Roberto Moscati, and Massimiliano Vaira, "The academic workplace. Country report Italy," in The work situation of the academic profession in Europe: Findings of a survey in twelve countries, ed. Jürgen Enders and Egbert de Weert, (Frankfurt am Main: Gewerkschaft Erziehung und Wissenschaft, 2004), 243-263.

${ }_{66}$ Michele Rostan, La professione accademica in Italia. Aspetti, problemi e confronti nel contesto Europeo (Milano: LED, 2011).

${ }^{67}$ Alenoush Saroyan and Cheryl Amundsen, "Evaluating university teaching. Time to take stock," Assessment \& Evaluation in Higher Education 26 (2001): 341-53, https://doi. org/10.1080/02602930120063493.

${ }_{68}$ John Biggs and Catherine Tang, Teaching for quality learning at university. 4th ed. (Maidenhead: McGraw Hill Education, 2011).

69 Alenoush Saroyan and Keith Trigwell, "Higher education teachers' professional learning. Process and outcome," Studies in Educational Evaluation 46 (2015): 92-101, https:// doi.org/10.1016/j.stueduc.2015.03.008.

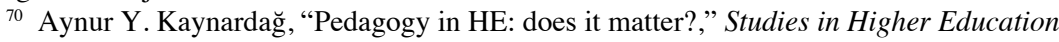
44 (2019): 1-9, https://doi.org/10.1080/03075079.2017.1340444. 
and Tang ${ }^{71}$ highlighted how processes, such as the definition of learning outcomes, the selection of the type of student learning assessment and module design, exert a major impact in promoting an effective and studentcentred teaching for the contemporary university. Kaynardağ's work ${ }^{72}$ investigated the 'core pedagogical skills' that university teachers should possess by providing three main dimensions of analysis, i.e. delivery (of knowledge), communication between teachers and the assessment of student learning.

Conversely, Saroyan and Amundsen ${ }^{73}$ and Saroyan and Trigwell ${ }^{74}$ reflected on two debated issues of the teaching process, i.e. goals, role and potential unintended consequences of the evaluation of students' opinions, and the relevance and impact of faculty development on the quality of learning and teaching processes.

Consequently, seven teaching practices and processes have been identified. Some practices are related to the 'pedagogical skills' of teachers, in other words, the delivery of knowledge (teaching methods), the communication between teachers and students and the assessment of students' learning, which have a substantial impact on the teacher/student relationship. Other practices are related to the organisational design of modules, in particular the coordination of teachers, the management of the study workload, the definition of learning outcomes and the faculty development. These are practices in which a teacher is forced to deal with the directives and initiatives of universities, although these have a direct impact on students. Finally, another significant element is the students' feedback, intended as both a bottom-up teaching improvement tool and an internal teaching control system. The association between the seven teaching practices and the two dimensions of analysis are summarised in Table 1.

${ }^{71}$ John Biggs and Catherine Tang, Teaching for quality learning at university. 4th ed. (Maidenhead: McGraw Hill Education, 2011).

72 Aynur Y. Kaynardağ "Pedagogy in HE: does it matter?," Studies in Higher Education 44 (2019): 1-9, https://doi.org/10.1080/03075079.2017.1340444.

${ }^{73}$ Alenoush Saroyan and Cheryl Amundsen, "Evaluating university teaching. Time to take stock.," Assessment \& Evaluation in Higher Education 26 (2001): 341-53, https://doi. org/10.1080/02602930120063493.

${ }^{74}$ Alenoush Saroyan and Keith Trigwell, "Higher education teachers' professional learning. Process and outcome," Studies in Educational Evaluation 46 (2015): 92-101, https:// doi.org/10.1016/j.stueduc.2015.03.008. 


\section{Table 1}

Teaching practices investigated in the interviews.

\begin{tabular}{|l|c|c|}
\hline \multirow{2}{*}{ Teaching Practice } & \multicolumn{2}{c|}{ Dimension of Analysis } \\
\cline { 2 - 3 } & Teacher-University & Teacher-Students \\
\hline $\begin{array}{l}\text { Module design and coordinating } \\
\text { mechanisms among teachers (I) }\end{array}$ & $\mathrm{X}$ & \\
\hline Learning outcomes and ETCS credits (II) & $\mathrm{X}$ & $\mathrm{X}$ \\
\hline $\begin{array}{l}\text { Communication between teacher and } \\
\text { students (III) }\end{array}$ & & $\mathrm{X}$ \\
\hline Teaching methods (IV) & $\mathrm{X}$ & $\mathrm{X}$ \\
\hline Assessment of student learning (V) & $\mathrm{X}$ & $\mathrm{X}$ \\
\hline Training programmes for teachers (VI) & $\mathrm{X}$ & \\
\hline $\begin{array}{l}\text { Evaluation of teaching from students } \\
\text { (VII) }\end{array}$ & & \\
\hline
\end{tabular}

$\mathrm{X}=$ relation between teaching practice covered in the interviews and the two relationships.

These teaching practices found in the literature were the main subject of 90 in-depth interviews with teachers in charge of modules in undergraduate courses $^{75}$. The interviewees were academics at different career levels (full professors, associate professors, assistant professors) with at least three years of activity and with full responsibility of their modules. Interviews have been taken at the end of 2015 - beginning of 2016 during a field research sponsored by the Giovanni Agnelli Foundation and Italian Publishing Association. ${ }^{76}$ Interviews were recorded, and the interviewees were guaranteed anonymity. The interviews were carried out in six disciplinary areas in order to take into account the influence of a discipline on the teacher's behaviour. ${ }^{77}$ Based on the 'Becher-Biglan' classification, ${ }^{78}$

${ }^{75}$ By 'course' we mean academic (undergraduate or postgraduate) degree programme. By the term 'module' we mean a unit of teaching (subject) in a curriculum.

${ }^{76}$ Fondazione Giovanni Agnelli (FGA), "La didattica in università: Una ricerca nelle differenti discipline - Analisi delle modalità didattiche, degli strumenti per la verifica degli apprendimenti e dello studio individuale," (2016), http://www.fondazioneagnelli.it/2016/09/29/ la-didattica-alluniversita/ [In Italian.].

77 Tony Becher and Paul R. Trowler, Academic tribes and territories. 2nd ed. (Buckingham: Open University Press, 2001).

${ }^{78}$ Ruth Neuman, Sharon Parry, and Tony Becher, "Teaching and learning in their disciplinary contexts. A conceptual analysis," Studies in Higher Education 27 (August 2002): 
the selected disciplines were Chemistry and Medicine as 'Hard-Pure' disciplines, Industrial Engineering as a 'Hard-Applied' discipline, Philosophy, Law respectively as 'Soft-Pure' and Management as 'SoftApplied' disciplines.

Finally, although the selection of the interviewees does not intend to have a sampling value, it was conducted in order to take into account the differences of Italian academics with an equal representation of gender ( $44 \%$ female e $56 \%$ male), age, and geographical location of the universities, thus increasing the generalisation of the findings. ${ }^{79}$ The interviews were carried out as face-to-face interviews on site. Each interview was conducted and analysed by two different researchers and then discussed collectively in order to identify relevant examples and main trends.

\section{Results ${ }^{80}$}

\section{VI.1. Module design and coordinating mechanisms among teachers}

The level of coordination with colleagues in the organisation of teaching activities was analysed in relation to the relationship between teachers and university. Only $38 \%$ of the interviewees reported attending formal meetings with the teaching staff (scheduled and organised on the basis of internal rules) to discuss the contents of their modules with their colleagues. In general, there was a tendency to coordinate undergraduate courses through informal and unstructured meetings with the teaching staff.

\#Law 12: «Module design is left to the autonomy of each teacher. Once the class schedule is set, teachers work in complete autonomy.»

\#Management 11: «The contents of the module and its organisation are established by each teacher in a fully autonomous way...»

The interviews show a concept of coordination as occasional and limited to unstructured, fragmentary, partial experiences on a voluntary

405-17, https://doi.org/10.1080/0307507022000011525.

${ }^{79}$ Robert K. Yin, Case study research, design and methods, 2nd ed. (Thousand Oaks: Sage Publications, 1994).

${ }^{80}$ Below a synthesis of the research results is presented. For more clarification, some statements of people interviewed are reproduced. The excerpts of each interview have been marked to identify the discipline of the interviewee. 
basis. The formal meetings are scheduled in an annual general meeting where each teacher briefly presents the contents of their modules for the following year. Significantly, in the cases where no coordination mechanism is reported $(22 \%)$, teachers believe that this custom is anything but positive and that greater coordination would be beneficial to improving the learning process of their students.

\#Management 7: «We do not have any coordinating mechanisms, but this would be beneficial for both students in order to avoid that different teachers overlap on the contents of their modules.»

Concerning disciplines, the interviews highlighted that there was greater (mostly informal) coordination in the scientific courses (Chemistry and Engineering). In Medicine, where teaching practices tend to comply with models promoted by the EU, coordination is more widespread because of the integrated courses where several teachers give specific modules within a larger course. In this case, coordination is implemented and is often effective.

\#Medicine 7: «In the teachers' periodic meeting we happen to talk to our colleagues about the main notions provided in our modules that will be used as basic knowledge in other modules. These connections are based on individual agreements among teachers. There was an attempt to institutionalise it, but it didn't work out.»

\section{VI.2. Learning outcomes and ETCS credits}

The use of the Dublin Descriptors in designing modules and identifying the learning outcomes expected by the Course Council and the ration between the students' workload and ECTS credits are analysed in relation to both the relationship between researchers and university and the relationship between teachers and students. The Dublin Descriptors are general statements on the typical results obtained by students after completing a degree; these have been used as a way to identify the expected learning outcomes of modules and programmes. Although their use has been required in Italy by legal provision and has been included in all the official documents required to establish the content of modules for many years, the interviews showed that almost all the interviewees lacked awareness of how their modules contributed to the achievement of the learning outcomes expected by the degree programme. Moreover, a few interviewees expressed hostility and annoyance towards this type of tools, which are thought to limit the degree of educational autonomy. 
\#Engineering 12: «These things don't make much sense to me. A university student is supposed to conduct in-depth and high-profile studies. I don't like all this experientialism. You go to university to learn.»

Another aspect concerned the balance between ECTS credits and student workload. What clearly emerged was that there were usually no established processes to assess this balance. The teachers considered their credits appropriate but without verifying their consistency. The opinion of students was not deemed objective.

\#Philosophy 2: «The study load is never enough for teachers while it is always too much for students.»

\#Chemistry 1: «ECTS credits are often distributed based on the teachers' power and no other criteria.»

The teacher is still in charge of establishing the balance between student workload and teaching. The lack of consistency between ECTS credits and workload is relevant, considering that only $26.8 \%$ of the students in Italy finish their courses within the time limit. ${ }^{81}$

In relation to the disciplines, the interviews show that in Hard Science programmes (Chemistry and Engineering), there is a good level of coordination, especially informal coordination. In Medicine, where the teaching model is mostly based on EU standards, there is a high level of coordination and seems to give good results. The level of coordination in Law and, above all, in Management is decidedly more limited.

\section{VI.3. Communication between teacher and students}

An aspect connected with the relationship between teachers and students that was taken into account was the availability and accuracy of the information about the module on the programme web pages managed by teachers. This information is normally available on the university's website; however, although there is often a common format, this information is far from detailed. For instance, the information concerning the assessment of student learning methods of the module is often too succinct, as only the examination type (written/oral) is mentioned without any further information

${ }^{81}$ Agenzia Nazionale di Valutazione del Sistema Universitario e della Ricerca (ANVUR), "Rapporto sullo Stato del Sistema Universitario e della Ricerca 2016" (2016), http://www. anvur.it/wp-content/uploads/2016/07/ANVUR_Rapporto_INTEGRALE_ .pdf [In Italian.]. 
about the contents or the methodology of the test and the link between the exam and the learning objectives.

Nonetheless, a good level of communication between teachers and students was found in relation to the coordination required for organisational aspects (such as exam management, exam scheduling, management of classrooms and laboratories). This information is usually provided both in the classroom (especially with a small number of students with whom the teacher can have a direct relationship) and the evaluation questionnaires for each module.

\#Medicine 5: "In the planning phase there are a few teaching-related meetings to address and resolve potential problems, also on the basis of the students' opinions.»

\#Management 4: «We listen to the students' opinions especially when there are organisational issues causing an exam, class or other activities to be rescheduled.»

\#Management 15: «We regularly publish online information about didactic organisation which is very useful for students.»

\section{VI.4. Teaching methods}

The teaching methods were analysed by considering both the teacheruniversity relationship and the teacher-student relationship. The interviews showed how the teachers seemed to be aware of the importance of teaching methods and their impact on the learning process.

\#Law 6: «When I start by analysing a case study, I see students are much more attentive. Compared to more traditional ways of teaching, it is a plus.»

\#Chemistry 15: «In a laboratory, students have to teach themselves. The shift from theory to practice is fundamental. We have often discussed this, but in Chemistry we heavily rely on independence in learning.»

Despite this awareness, there is no systemic consideration (especially in the organisation of the modules) regarding the best methods to deliver the education programme. There are few opportunities to discuss this topic with colleagues and, especially, in the course council. Similarly, students are not very involved in the choice of teaching methods. The teacher who chooses his teaching method according to his own preferences. The interviews did 
not reveal any mechanism to match teaching methods with the characteristics and needs of students.

Conversely, the influence of the discipline on teaching methods is very strong. In a few cases, this link with teachers of the same discipline in other degree courses and universities (which is not surprising if we consider universities as professional bureaucracies) seems to lead to a conservative attitude in teaching methods, i.e., it makes changes really slow and takes them out of the specific context of a degree programme.

\#Law 3: «I do frontal lessons, slide presentations may be useful, but I prefer interacting with my students, I've always been accustomed to teach without them, so it'd be difficult to me to use them during class.»

\#Philosophy 11: «They are all frontal lessons, I decided not to use slide presentations, I read texts in class, it may seem and old-fashioned method, but my students appreciate it because they can no longer read the texts.»

All interviews showed that classrooms were still a binding component in the selection of a teaching method. For instance, whenever there was a large number of students in the classrooms, teachers tended to choose a teaching method based on frontal lessons.

\section{VI.5. Assessment of student learning}

Another area which is significant for both (teacher-university and teacherstudent) relationships was the assessment of student learning methods. This is the area where teachers are most autonomous. Assessment is central in quality assurance processes and is under the responsibility of universities and degree programmes. In general, teachers tend not to spend much time in reflecting on the best evaluation method to assess knowledge acquisition.

\section{\#Philosophy 4: «I use oral exams. It's always been like this»}

The reasons underlying the choice of a test method are often practical (such as the number of students in the classroom) and may be influenced by the traditional methods in each discipline. There are a few exceptions (more specifically in Medicine) where there is a sound reflection on the impact of assessment methods on the expected results and, especially, on the students' post-university careers.

In most cases, the choice of an assessment method is made by teachers autonomously. Assessment is generally considered by most teachers as a personal matter where the course coordinator has no influence. 
\#Management 14: "These are decisions taken independently. If I choose always the same specific assessment method is because I retain this is the most suitable to evaluate students»

\#Law 3: "University teachers are responsible for their choices but sometimes this leads to exaggeration because students - and not the teacher's narcissism - should be placed at the forefront»

There are also substantial differences in each discipline in relation to assessment methods.

Finally, as regards the nature of assessment, even though there have been various experiences of self-evaluation so far, these are still not very frequent, which points out how "summative" assessment (i.e. the assessment used for the final mark) is considerably predominant as compared to "formative" assessment (i.e. the assessment used during the course to test and improve the student's preparation).

\section{VI.6. Training programmes for academics}

Another area of analysis was the interviewees' opinions on the training initiatives for academic teaching. The focus here is on the relationship between teachers and university. The question sets out to explore whether the teachers were aware of possible training initiatives for teaching and to learn their reaction. This topic is significant in relation to the ESG (European Standard and Guidelines), where one of the priorities is the implementation of training courses on teaching skills for academics. The interviewees had different opinions on this topic: half stated that they would attend such initiatives, whereas the other half were firmly against these courses as they were deemed useless. Less than $40 \%$ of the interviewees claimed to have been involved in a teaching training initiative.

\#Chemistry4: "The only useful training for young academics is research. I'm evaluated based on my research performances, not the teaching ones.»

\#Medicine 11: "I attended a course and I found helpful to improve my teaching skills.»

\#Law9: «No, the university doesn't help at all. Teacher are assumed to be already skilled. That's the typical job that no one teaches you. At the very least, public speaking courses would be useful.»

It is significant that, in the universities where the interviews took place, there was no structured and widespread training programme for teachers. 
Training actions were taken on a voluntary basis, often linked to and promoted by the teachers' disciplines, and always at the first stages of a university career. In particular, from the interviews, Medicine and Engineering emerge as more prone to training initiatives.

\section{VI.7. Evaluation of teaching by students}

Student evaluation of teaching was examined in relation to the relationship between teachers and university and the relationship between teachers and students. The interviewees tended to be in favour of receiving feedback from students in relation to their satisfaction and they believed that it was useful to improve their teaching skills.

\#Medicine 2 «It's critical. The offer has been improved every year based on the previous year's feedback.»"

\#Chemistry 2 «Results are taken into consideration. Student reports are taken into account.»"

However, there were some critical aspects and differences in the disciplines. The main general issues reported in this respect were: the anonymity of questionnaires, which is supposed to decrease the student's commitment while answering; the difficulty in involving students and the evaluation timing, especially when questionnaires were given in digital format before registering for an exam; difficulty in distinguishing between attending and non-attending students in questionnaires; the lack of qualitative comments, especially in the digital forms; the deficient information that can be gathered through the Ministerial format for the questionnaires; the students' lack of awareness of the feedback process. These criticisms, nevertheless are not detrimental to the improving effect of the results of satisfaction questionnaires $(70 \%$ of the interviewees were in favour of them), whereas there is more resistance when questionnaires are used to determine organisational choices.

\#Management 1: «They are certainly helpful at the individual level as an incentive to improve one's skills. Their use at the organisational level (for instance for rewards and punishments in departments) is dangerous for me.»

The credit given by the teachers to the results of the questionnaires varies amongst disciplines. Chemistry and Management teachers are more collaborative, while Philosophy teachers are much more cautious. 


\section{Discussion and conclusion}

As already mentioned, the profession of university teacher is evolving as a consequence of the new functions of universities..$^{82,83}$ The academic world is generally reluctant to change, especially when it comes to an external influence on individual autonomy. In the Italian case, the resistance to change is also linked to the characteristics of the Italian academia, which was traditionally characterised by corporative bodies (guilds) and their relationship with the central government, as teachers are also considered civil servants. ${ }^{84}$ The picture emerging from this study shows that university teachers find it hard to change and adapt their professional role with respect to the relationship between teachers and university (I dimension) and teachers and students (II dimension).

Concerning the first relationship (I dimension), there is a need to overcome the characteristics and limits of professional bureaucracy where the control of professionals is limited to the standardisation of the entrylevel competences or certain stages of career progression. ${ }^{85}$ The interviews confirmed that academics, once they had acquired their position, tended to consider the coordination activities with their colleagues (e.g., when laying down the module content to establish the student workload compared to the other modules) as a violation of the teacher's professional autonomy. This is likely to couple with the traditional resistance to innovation of this profession. This reluctance and the limited ability to change result from the fact that the innovations (e.g., new teaching methods or the increasing focus on certain student categories) require collaboration among professionals and the capacity to adapt teaching patterns to new operational modes. When there is reluctance to change, the top-down imposition of innovative tools, such as the Dublin Descriptors or the ECTS credits, results in a mere cosmetic implementation with no real impact on academic attitudes. The

82 Joëlle Fanghanel and Paul Trowler, "Exploring academic identities and practices in a competitive enhancement context: a UK-based case study," European Journal of Education 43 (August 2008): 301-13, https://doi.org/10.1111/j.1465-3435.2008.00356.x.

${ }^{83}$ John Dirkx and Anna Serbati, "Promoting faculty professional development: strategies for individual and collective reflection towards institutional change," in Preparare alla professionalità docente e innovare la didattica universitaria, ed. Ettore Felisatti and Anna Serbati (Milano: Franco Angeli, 2017), 21-28.

${ }^{84}$ Guy Neave and Gary Rhoades, "The academic estate in Western Europe," in The academic profession. National, disciplinary and institutional settings, ed. Burton R. Clark (Berkeley: University of California Press, 1987).

${ }^{85}$ Henry Mintzberg, The structuring of organizations: A synthesis of research (Englewood Cliffs: Prentice-Hall, 1979). 
only exceptions are organisational provisions, such as those regarding the communication with students and their organisational needs, that can be promoted by the top management of the university with little effect on the professional autonomy of the teachers.

However, the difficulties between teachers and universities are not only on the teachers' side. The data gathered in this study highlight that universities fail to support the teachers' increased interest in the evolution of teaching needs. In this respect, there is a missed opportunity in terms of teaching training and activities supporting teaching innovation, as shown by the interviewees' interest in this topic. What is more, the coordination and control activities promoted by the government and universities, instead of encouraging a change in the professional role of teachers, ended up fossilising or even undermining it. As indicated by the interviews, both the entry and promotion processes and the evaluation mechanisms focus on rewarding research activities. In this framework, didactical innovation and teachers' training when perceived as top-down initiatives or linked to quality assurance policies at national level, are often interpreted more as obligations determined by an intrusive bureaucracy than a cultural chance. ${ }^{86}$ Nevertheless, unbalance favouring research has not discouraged any bottom-up improvement in teaching methods. ${ }^{87}$

The second aspect, the relationship between teachers and students (II dimension), should take into account the purposes and expectations of teachers. In reality, a two-fold tendency emerged in our study. On the one hand, the relationship with students encourage teachers to be interested in their conditions and the best teaching methods. This is reflected in the individual interest shown by teachers in the results of the teacher evaluation questionnaires and, more generally, in teaching methods. After all, the academic profession originates as a knowledge transfer process (from a person who has knowledge to a person who does not) thus, it is not surprising to find this attention of teachers to their students.$^{88}$ On the other hand, despite this growing interest, teachers are alone because universities fail to provide tools to help them to understand the students' needs in terms of leaning and to support teaching innovation in relation to competences as

${ }^{86}$ Ettore Felisatti and Anna Serbati, Preparare alla professionalità docente e innovare la didattica universitaria (Milano: Franco Angeli, 2018).

${ }^{87}$ Charlotte Silander and Martin Stigmar, "Individual growth or institutional development? ideological perspectives on motives behind Swedish higher education teacher training," Higher Education 77 (2019): 265-281, https://doi.org/10.1007/s10734-018-0272-z.

${ }^{88}$ Peter M. Blau, The organization of academic work (New York: John Wiley \& Sons, 1973). 
well as investment incentives. This clearly emerged in relation to assessment of student learning: Italian teachers are free to choose their evaluation methods without questioning the consistency between assessment methods and learning objectives. This is in line with the traditional idea of academics, where one of the key features is the rejection of the role of students as clients, even to the detriment of meeting their needs and the changing of the teaching goals ${ }^{89}$ This focus on students is not codified and regulated by minimum service standards and therefore relies on the professional sensitivity of teachers whose key function is the transmission of knowledge. In this context, they are left to their own devices to establish contents, teaching methods and assessment. Nevertheless, this loneliness leads to problems that the teachers themselves admit in the interviews. However, the awareness is not enough to win the resistance of a considerable part of the respondents against teaching support programmes starting, from the willingness to favourably consider the training regarding pedagogical competencies as potential added value..$^{90}$

Following the typical approach of professional bureaucracy, this lack of guidance is counteracted by disciplinary communities which provide theoretical approaches and professional templates. The data stress the impact of disciplines on teaching practices. The discipline has a greater influence on the relationship between students and teacher than the university institution. ${ }^{91}$ In fact, the interviews showed that lesson planning, and assessment methods mainly depended on the teacher's discipline.

This aspect (i.e., the relevance of disciplines) determines the main limitations of this study and provides directions for further research. Limitations are related to the fact the interviews clearly showed the relevance of disciplines in influencing the teaching behaviours of academics. Therefore, there is much room for further research on the aspects determining different behaviours and different attitudes towards change according to the discipline. In particular, the role of disciplines in favouring or hindering teaching innovation is certainly a topic that requires further study in order to verify whether disciplines can be involved in the development of teaching policies to facilitate success at both national and university level.

${ }^{89}$ Peter M. Blau, The organization of academic work (New York: John Wiley \& Sons, 1973).

90 Aynur Y. Kaynardağ, "Pedagogy in HE: does it matter?," Studies in Higher Education 44 (2019): 1-9, https://doi.org/10.1080/03075079.2017.1340444.

91 Anna Bager-Elsborg, "How lecturers' understanding of change is embedded in disciplinary practices: A multiple case study," Higher Education 76 (2018): 195-212, https:// doi.org/10.1007/s10734-017-0195-0. 


\section{Bibliography}

Agasisti, Tommaso, Giovanni Barbato, Martina Dal Molin, and Matteo Turri. "Internal quality assurance in universities: does NPM matter?" Studies in Higher Education (November 2017). https://doi.org/10.1080/03075079.2017.1405252.

Agenzia Nazionale di Valutazione del Sistema Universitario e della Ricerca (ANVUR). "Rapporto sullo Stato del Sistema Universitario e della Ricerca 2016.” 2016. http://www .anvur.it/wp-content/uploads/2016/07/ANVUR_ Rapporto_INTEGRALE_ .pdf. [In Italian.]

Astin, Alexander W. "Student involvement: A developmental theory for higher education.” Journal of College Student Personnel 25 (1984): 297-308.

Bager-Elsborg, Anna. "How lecturers' understanding of change is embedded in disciplinary practices: a multiple case study." Higher Education 76, no. 2 (August 2018): 195-212. https://doi.org/10.1007/s10734-017-0195-0.

Becher, Tony, and Paul R. Trowler. Academic tribes and territories. 2nd ed. Buckingham: Open University Press, 2001.

Biggs, John, and Catherine Tang. Teaching for quality learning at university. 4th ed. Maidenhead: McGraw Hill Education, 2011.

Billing, David. "Teaching for transfer of core/key skills in higher education: Cognitive skills." Higher Education 53, no. 4(2007): 483-516. https://doi. org/10.1007/s10734-005-5628-5.

Blau, Peter M. The organization of academic work. New York: John Wiley \& Sons, 1973.

Boffo, Stefano, and Roberto Moscati. "Evaluation in Italian higher education system. Many tribes, many territories, many...godfathers." European Journal of Education 33, no. 3 (1998): 349-360.

Boffo, Stefano, Roberto Moscati, and Massimiliano Vaira. "The Academic Workplace. Country Report Italy." In The International Attractiveness of the Academic Workplace in Europe. Edited by Jürgen Enders and Egbert de Weert, 243-263. Frankfurt am Main: Gewerkschaft Erziehung und Wissenschaft, 2004.

Capano, Giliberto. "Government continues to do its job: a comparative study of governance shifts in the higher education sector." Public Administration 89, no. 4(December,2011): 1622-42.https://doi.org/10.1111/j.1467-9299.2011.01936.x.

Capano, Giliberto, Marino Regini, and Matteo Turri. Changing governance in universities. Italian higher education in comparative perspective. London: Palgrave Macmillan, 2016.

Cardoso, Sónia, Maria J. Rosa and Bjørn Stensaker. "Why is quality in higher education not achieved? The view of academics." Assessment \& Evaluation in Higher Education 41, no. 6 (2016): 950-65.

Choi, Bo Keum, and Byung Shik Rhee. "The influences of student engagement, institutional mission, and cooperative learning climate on the generic competency development of Korean undergraduate students." Higher Education 67, no. 1 (2014): 1-18. https://doi.org/10.1007/s10734-013-9637-5. 
Clark, Burton R. Academic power in Italy. Bureaucracy and oligarchy in a national university system. Chicago: The University of Chicago Press, 1977.

Clark, Burton R. The higher education system. Academic organization in crossnational perspective. Berkeley: University of California Press, 1983.

Coggi, Cristina, and Paola Ricchiardi. "Developing effective teaching in higher education.”Form@re - Open Journal Per La Formazione In Rete 18 (2018): 23-38. https://doi.org/10.13128/formare-22452.

Devlin, Marcia, and Gayani Samarawickrema, "The criteria of effective teaching in a changing higher education context." Higher Education Research and Development 29, no. 2 (2010): 111-124. https://doi.org/10.1080/07294360903244398.

Dill, David D., and Maarja Soo. "Academic quality, league tables, and public policy: A cross-national analysis of university ranking systems." Higher Education 49, no. 4 (2005): 495-533. https://doi.org/10.1007/s10734-004-1746-8.

Dirkx, John, and Anna Serbati. "Promoting faculty professional development: strategies for individual and collective reflection towards institutional change." In Preparare alla professionalità docente e innovare la didattica universitaria, edited by Ettore Felisatti and Anna Serbati, 21-28. Milano: Franco Angeli, 2017.

Enders, Jurgen. Academic Staff in Europe. Changing Contexts and Conditions. London: Greewood Press, 2001.

European Association for Quality Assurance in Higher Education (ENQA). "European Standards and Guidelines (ESG) 2015." https://enqa.eu/index.php/ home/esg/. [In English.]

Esdar, Wiebke, Julia Gorges, and Elke Wild. "The role of basic need satisfaction for junior academics' goal conflicts and teaching motivation." Higher Education 72, no. 2 (2016): 175-90. https://doi.org/10.1007/s10734-015-9944-0.

Entwistle, Noel. Teaching for understanding at university. Basingstoke: Palgrave, 2009.

Fanghanel, Joëlle, and Paul Trowler. "Exploring Academic Identities and Practices in a Competitive Enhancement Context: a UK-based case study." European Journal of Education 43, no. 3 (2008): 301-13. https://doi. org/10.1111/j.1465-3435.2008.00356.x.

Fondazione Giovanni Agnelli (FGA). La didattica in università: una ricerca nelle differenti discipline - Analisi delle modalità didattiche, degli strumenti per la verifica degli apprendimenti e dello studio individuale. 2016. Slidebook_AIE_FGA http://www.fondazioneagnelli.it/2016/09/29/la-didattica-alluniversita/. [In Italian.]

Ettore, Felisatti, and Anna Serbati. Preparare alla professionalità docente e innovare la didattica universitaria. Milano: Franco Angeli, 2017.

Goode, William J. "The Theoretical Limits of Professionalization.” In The SemiProfessions and their Organization, edited by Amitai Etzioni, 266-313. New York: The Free Press, 1969.

Harvey, Lee and Jethro Newton. "Transforming quality evaluation." Quality in Higher Education 10, no. 2 (2004): 149-65, https://doi.org/10.1080/1353832042 000230635 . 
Harvey, Lee and Jethro Newton. “Transforming Quality Evaluation: Moving On.” In Quality Assurance In Higher Education, edited by Don F. Westerheijden, Bjør Stensaker and Maria J Rosa, Higher Education Dynamics vol 20. Dordrecht: Springer, 2007. https://doi.org/10.1007/978-1-4020-6012-0_9.

Henkel, Mary. Academic identities and policy change in higher education. London: Jessica Kingsley Publisher, 2000.

Hoehle, Ester Ava, and Ulrich Teichler. "The Teaching Function of the Academic Profession." In The Work Situation of the Academic Profession in Europe: Findings of a Survey in Twelve Countries, edited by Ulrich Teichler and Ester Ava Hoehle, 79-108. Dordrecht: Springer, 2013.

Horta, Hugo, Vincent Dautel, and Francisco M. Veloso. "An output perspective on the teaching-research nexus. An analysis focusing on the United States higher education system." Studies in Higher Education 37, no. 2 (2012): 171-87. https://doi.org/10.1080/03075079.2010.503268.

Hughes, Everett C. Men and Their Work. New York: The Free Press, 1958.

Kaynardağ, Aynur Yürekli. "Pedagogy in HE: does it matter?" Studies in Higher Education 44, no. 1 (2019): 111-119. https://doi.org/10.1080/03075079.2017.13 40444.

Krause, Elliott A. "Les guildes, 1'Etat et la progression du capitalisme. Les professions savantes des 1930 à nos jours." Sociologie et Sociétés 20, no. 2 (1988): 91-124. https://doi.org/10.7202/001391ar.

Larson-Sarfatti, Magali. The rise of professionalism: A sociological analysis. Berkeley: The University of California Press, 1977.

Leiber, Theodor, Bjørn Stensaker, and Lee Harvey. "Impact evaluation of quality assurance in higher education: methodology and causal designs." Quality in Higher Education21,no3(2015):288-311.https://doi.org/10.1080/13538322.2015.1111007.

Light, Donald Jr. "The structure of the academic professions." Sociology of Education 47, no. 1 (1974): 2-28. https://doi.org/10.2307/2112165.

Louvel, Séverine. "Understanding change in higher education as bricolage: how academics engage in curriculum change." Higher Education 66, no. 6 (2013): 669-691. https://doi.org/10.1007/s10734-013-9628-6.

Mintzberg, Henry. The structuring of organizations: A synthesis of research. Englewood Cliffs: Prentice-Hall, 1979.

Moscati, Roberto. (Ed.). Chi governa l'università? Il mondo accademico italiano tra conservazione e mutamento. Napoli: Liguori, 1997.

Moscati, Roberto, ed. Come e perché cambiano le università in Italia e in Europa. Napoli: Liguori, 2010.

Musselin, Christine. "Redefinition of the relationships between academics and their university." Higher Education 65, no. 1 (2013): 25-37. https://doi.org/10.1007/ s10734-012-9579-3.

Neave, Guy, and Gary Rhoades. "The Academic Estate in Western Europe.” In The Academic Profession. National, Disciplinary and Institutional Settings, edited by Burton R. Clark. Berkeley: University of California Press, 1987. 
Neuman, Ruth, Sharon Parry, and Tony Becher. "Teaching and learning in their disciplinary contexts. A conceptual analysis." Studies in Higher Education 27, no. 4 (2002): 405-17. https://doi.org/10.1080/0307507022000011525.

Nigris, Elisabetta. "Learning to teach: the pilot programme to improve faculty members teaching skills at the University of Milano-Bicocca." Form@are Open Journal Per la Formazione in Rete 18, no. 1 (2018): 53-66. https://doi. org/10.13128/formare-22603.

Nowotny, Helga. The cunning of uncertainty. Cambridge: Polity Press, 2016.

Piper, David Warren. "Are Professors Professionals?" In The Organization of University Examination, edited by David Warren Piper, 1-18. London: J. Kingsley, 1994.

Polanyi, Michael. "The republic of science. Its political and economic theory." Minerva 38, no. 1 (1962): 54-73.

Rostan, Michele, ed. La professione accademica in Italia. Aspetti, problemi e confronti nel contesto Europeo. Milano: LED, 2011.

Saroyan, Alenoush, and Cheryl Amundsen. "Evaluating university teaching. Time to take stock." Assessment \& Evaluation in Higher Education 26, no. 4 (2001): 341-53. https://doi.org/10.1080/02602930120063493.

Saroyan, Alenoush, and Keith Trigwell. "Higher education teachers' professional learning. Process and outcome." Studies in Educational Evaluation 46 (2015): 92-101. https://doi.org/10.1016/j.stueduc.2015.03.008.

Suleman, Fátima. "The employability skills of higher education graduates: insights into conceptual frameworks and methodological options." Higher Education 76, no. 2 (2018): 263-78. https://doi.org/10.1007/s10734-017-0207-0.

Silander, Charlotte, and Martin Stigmar. "Individual growth or institutional development? Ideological perspectives on motives behind Swedish higher education teacher training." Higher Education 77, no. 2 (2019): 1-17. https://doi. org/10.1007/s10734-018-0272-z.

Shinn, Larry D. "Liberal education in the age of the unthinkable." Change: The Magazine of Higher Learning 44 (2012): 15-21 . http://doi.org/10.1080/0009138 3.2012.691858.

Teichler, Ulrich. "Changing perspectives. The professional relevance of higher education on the way towards the highly-educated society." European Journal of Education 50, no. 4 (2015): 461-77. https://doi.org/10.1111/ejed.12146.

Teichler, Ulrich, Akira Arimoto and William K. Cummings. The changing academic profession. Major findings of a comparative survey. Dordrecht: Springer, 2013.

Turri, Matteo. "The new Italian agency for the evaluation of the university system (ANVUR): a need for governance or legitimacy?" Quality in Higher education 20, no. 1 (2014): 64-82. https://doi.org/10.1080/13538322.2014.889429.

Wilensky, Harold L. "The professionalization of everyone?" American Journal of Sociology 70, no. 2 (1964): 137-58.

Yin, Robert K. Case study research, design and methods. 2nd ed. Thousand Oaks: Sage Publications, 1994. 
Zheng, Lanqin, Xin Li, and Fengying Chen. "Effects of a mobile self-regulated learning approach on students' learning achievements and self-regulated learning skills." Innovations in Education and Teaching International 55, no. 6 (2018): 616-24. https://doi.org/10.1080/14703297.2016.1259080.

\section{About the authors}

GIOVANNI BARBATO (giovanni.barbato@unimi.it), PhD in Economic Sociology and Labour Studies, is presently Post-doctoral student in the Department of Economics, Management and Quantitative Methods (DEMM) at the Università degli Studi di Milano (Italy). His research interests focus on evaluation and qualuty assurance systems and strategy of public organizations, in particular higher education institutions.

ROBERTO MOSCATI (roberto.moscati@unimib.it), is full professor of Sociology of Education at the University of Milano-Bicocca (Italy). He is an external member of the "Presidio della Qualità". He has been member of the ministerial advisory group for the Italian higher education system (1995-1998); member of the Scientific Council of the Portuguese Agency for the Evaluation and Accreditation of Higher Education - A3ES (2015- to date). Moscati's principle fields of research are (i) comparative analysis of education systems; (ii) actors (teachers and students) in the education systems; and evaluation of systems of higher education and of University institutions.

MATTEO TURRI (matteo.turri@unimi.it), PhD in Management, is presently Associate Professor in Public Management in the Department of Economics, Management and Quantitative Methods (DEMM) at the Università degli Studi di Milano (Italy). His research centres on: (a) Management aspects in higher education sector with particular reference to governance systems, funding, evaluation, change management and the relationship between government bodies and universities; (b) Evaluation and control systems, focusing attention on the organizational effects of their implementation; (c) Management of public sector; (d) Governance and management of professional organizations. 


\title{
Is the role of academics as teachers changing? An exploratory analysis in Italian universities
}

\author{
Giovanni Barbato, Roberto Moscati, and Matteo Turri
}

doi: http://dx.doi.org/10.18543/tjhe-6(2)-2019pp97-126

\section{Copyright}

Copyright for this article is retained by the Publisher. It is an Open Access material that is free for full online access, download, storage, distribution, and or reuse in any medium only for noncommercial purposes and in compliance with any applicable copyright legislation, without prior permission from the Publisher or the author(s). In any case, proper acknowledgement of the original publication source must be made and any changes to the original work must be indicated clearly and in a manner that does not suggest the author's and or Publisher's endorsement whatsoever. Any other use of its content in any medium or format, now known or developed in the future, requires prior written permission of the copyright holder. 